\title{
Alternative approaches to control of parasites in livestock: Nordic and Baltic perspectives
}

\author{
Stig Milan Thamsborg ${ }^{*}$, Allan Roepstorff, Peter Nejsum, Helena Mejer \\ From Parasite infections of domestic animals in the Nordic countries - emerging threats and challenges. \\ The 22nd Symposium of the Nordic Committee for Veterinary Scientific Cooperation (NKVet) \\ Helsinki, Finland. 7-9 September 2008
}

\begin{abstract}
Introduction
It is evident from several on-farm surveys that levels of parasite infections vary markedly between livestock production systems and from one farm to another [1]. The background for these differences relates to livestock breeds, different management factors and other practices that directly or indirectly affect parasite infections, and also to farmers' attitudes e.g. the chosen threshold for intervention. This paper deals with practices or interventions that can be actively applied by farmers aiming specifically at control of mainly helminth infections, either by reducing the parasite infrapopulations directly, e.g. by means of antiparasitic crops, or by limiting the uptake of external stages, e.g. by pasture management. The term "alternative" approaches has been applied (despite several options not being very alternative or novel but relatively old) to denote only limited focus on use of commercial anthelmintics. Focus will be on approaches relevant to primarily ruminant and pig production and which can be applied in the Nordic-Baltic context after some modification or which may serve as a guideline for relevant research in our region. For practical reasons the options will be dealt with one at a time although, as pointed out in several reviews [2,3], the combination of two or more options, or the combination with limited use of anthelmintics, will in many cases be the optimal approach.
\end{abstract}

\section{Pasture management}

The basic principle of pasture management is limiting the intake of infective stages of pasture-borne parasite infections. Pasture management encompasses practices related to grazing: time of turn-out, length of grazing

Danish Centre for Experimental Parasitology, Department of Veterinary Disease Biology, Faculty of Life Sciences, University of Copenhagen, Denmark period, age composition of flocks, co-grazing with other species and frequency of pasture changes, although other factors like type of herbage and productivity, stocking rates and parasite contamination levels at turnout also are very important. On most ruminant farms, pasture management is guided by nutritional requirements of animals in combination with customary practices, and in general little attention is paid to parasites when the season's grazing is planned. Pasture management practices aiming at parasite control have been extensively researched (and reviewed by $[2,4,5]$ and in most cases demonstrated to be quite successful in controlling mainly gastrointestinal nematodes of ruminants. The strategies can be grouped as preventive i.e. starting off with low (or nil) infection levels in animals and on pastures, evasive i.e. moving animals away from pastures before harmful contamination levels are generated, or dilutive strategies i.e. lowering the ratio between susceptible and resistant animals (or lowering the overall stocking rate). Despite obvious benefits, these strategies are not readily adopted by cattle farmers, although still more by organic than conventional farmers $[6,7]$, and this may be related to the relative ease and low cost of using anthelmintics compared to labour-intensive fencing and moving. Furthermore, in sheep grazing management is difficult to practice totally without drugs.

In dairy cattle, the most susceptible group of animals, i.e. first season grazing calves, is uninfected at turn-out and if placed on an uninfected (or lightly contaminated) pasture this will result in good control for the first half of the season. By repeated moves to clean pastures (e.g. 2-3 times), excellent control is obtained for the entire season [8]. Even though the first paddock is contaminated, infections are reduced if the flock is moved by 15 July to a paddock ungrazed the same year [9]. A recent Swedish study showed very convincingly that a practice of turning out 
first year grazing steers (castrated bulls) on paddocks grazed by second year grazers in the previous season combined with a mid-summer move to clean pasture, result in acceptable control of gastrointestinal nematodes [10]. Male animals are generally more susceptible to parasites than females and steers are believed to have intermediate susceptibility [11]. Recent Danish studies on nematode infections showed susceptibility in steers to be very similar to that of heifers [9]. Several studies have indicated an exacerbating effect of high stocking rates on gastrointestinal nematode infection levels in both cattle and sheep $[12,13]$ whereas the effect is less clear in outdoor pigs [14], which presumably is because pigs tend to stay in the feeding area instead of utilising the paddocks evenly.

Coccidia in ruminants are often transmitted by overwintering pasture infections from one year's young stock to the next [15], and clean pastures at turn-out (read ungrazed the previous year) are thus crucial in control [16]. This is a fact often overlooked by sheep or cattle farmers, e.g. if they have a permanent, after-lambing collecting paddock or if calves as a rule are grazed in close vicinity of the farm [17]. In the case of sheep, similar management practices may also result in problems of nematodirosis in early season ("lamb-to-lamb" disease) as observed in Denmark [18]. Increasing problems with liver flukes (Fasciola hepatica) are becoming evident in many places in Northern Europe where grazing of cattle is re-introduced on natural wetlands for aesthetical reasons and to maintain biodiversity [19]. In many cases control is achieved by strategic application of flukicides but it would be relevant to employ evasive grazing i.e. a move in mid-August as a means of control. However, few studies, if any, have addressed this approach.

The majority of the pig production in Nordic countries is indoor but pasture management is relevant in conventional outdoor and organic farming where the breeding stock, or all stock, have to be outside for a part of the year. The most common helminths (Ascaris suum and Trichuris suis) are characterized by hardshelled eggs and thus sustained longevity on pasture up to 10 years (reviewed by [1], despite initial high death rates [20]. Ongoing Danish experiments using parasite-naïve pigs to trace the levels of contamination on pastures after initial deposition of eggs, have yielded 2 interesting results: firstly, transmission levels are increasing the first 2 years, indicating an unexpected slow development to infectivity; secondly, infection levels were not markedly decreased after 4 years (Mejer and Roepstorff, 2006, unpublished data). This demonstrates fully that at present we cannot provide evidencebased recommendations with regard to paddock rotation in pigs - 2-3 years are obviously not enough! In contrast, it seems that Oeosphagostomum spp. have a poor survival over winter $[14,21,22]$ and do not constitute a problem in strictly outdoor sow herds [23] while the coccidian parasite Isospora suis seems to be controlled by routine moving of the farrowing huts between farrowings [24].

The principles of pasture management may be applied to indoor stabling of pigs in large pens with plenty of straw bedding, e.g. deep-litter systems. In these cases, the continuous use of a pen will inevitably lead to increasing levels of parasite infections [25] and all-outall-in systems need to be applied. With the forthcoming implementation of EU-legislation stipulating loose housing in enriched environments (e.g. wallowing) for sows for part of the gestation, an increased risk of helminth transmission may be anticipated.

\section{Bioactive crops and nutrition}

It is difficult to draw a clear distinction between bioactive crops, plant (herbal) medicine and nutrition as such. Bioactive crops (nutraceuticals) are plants containing secondary metabolites that are considered beneficial for their positive effect on animal health (in casu helminth control) rather than their direct nutritional value [26]. These crops can be used as fresh forages for grazing or as conserved feed in the daily ration without any adverse effect. They may be grown in the normal crop rotation and therefore draw some attention from commercial seed companies. In plant medicine dosing is usually a very critical issue and extraction steps are often included.

In small ruminants, extensive studies worldwide on bioactive crops have focused on forages rich in condensed tannins (4-8\% of dry matter) and their effect on gastrointestinal nematodes [26,27]. The relevant temperate/subtropical forages include sainfoin (Onobrychis viciifolia), sulla (Hedysarum coronarium) and larger trefoil (Lotus pedunculatus), all with limited distribution in Nordic-Baltic countries. Condensed tannins are secondary metabolites related to plant defence against herbivory and constitute a poorly defined group of polyphenolic compounds, based on flavan-3-ol monomers (prodelphinidins or procyanidins) and characterized by a protein-binding capacity (tanning!) [28]. The variability is large within condensed tannins and is related to plant species, growth conditions, stage of development, cuts etc. Due to this variability many findings are inconsistent or even contradictory. However, there is now ample evidence from in vitro and in vivo studies that forages with condensed tannins may affect all stages of parasitic nematodes, leading to reduced establishment of infective larvae, lowered fecundity of adult nematodes and in some cases, reduction in worm burdens. Effects have been observed against both abomasal and intestinal nematodes but this may, like in many other instances, depend on plant species or stage, e.g. the ratio between prodelphinidins and procyanidins [29]. It has long been debated whether the effects 
are direct by harming residing/incoming nematodes, or indirect by improving immunity through more rumenby-pass protein [28]. Recent studies have clearly indicated direct effects of condensed tannins from conserved sainfoin including inhibited exsheathment of infective larve, diminished pathological changes in larvae following short term exposure and reduced penetration of abomasal mucosa ([29,30]; Severine Brunet, pers. communication, 2008). A leafy cultivar of chicory (Cichorium intybus) suitable for ruminant grazing, although not rich in condensed tannins, does exhibit similar effects on nematodes, and this forage may prove to be more appropriate in the Nordic-Baltic context [31,26].

It has been known for more than a decade that structure and composition of the feed may influence establishment and fecundity of intestinal nematodes of monogastric animals [32]. A low fibre content and high level of easily fermentable carbohydrates may lower parasitism. Roots of chicory (Cichorium intybus) and seeds of lupin are rich in such fermentable carbohydrates, particularly fructans (inulin). In pigs, almost complete reduction of the egg output of Oesophagostomum spp. has been acheived by adding purified inulin [33] or dried chicory roots to the diet [22]. High reductions in worm counts have been observed in some studies [33,34] but not in all [22]. Incomplete elimination of worms may explain why depression of egg excretion has been partially reversible as egg counts were shown to increase when the carbohydrates were withdrawn from the diet ([33]; Helena Mejer, unpublished data, 2008). The fermentable carbohydrates are only partially degraded in the small intestine, and the mechanism of action is most likely related to the production of short chain fatty acids during their fermentation in the large intestine [35]. It is believed that the short chain fatty acids directly or indirectly cause adverse conditions for residing nematodes just as there is a shift in microbial composition [36]. Consequently, T. suis, another inhabitant of the large intestine, is moderately affected but results are inconsistent [37-39]. Furthermore, early larval stages of $A$. suum penetrate the large intestine before the migratory liver phase and establishment of incoming infections may be affected [22] but not established adult infections (Helena Mejer, unpublished data, 2008). As the major targets of nematode control in pig outdoor production in the Nordic context are indeed A. suum and $T$. suis, these findings need further investigation to be of practical relevance.

\section{Selective breeding for host resistance}

In ruminants, faecal egg counts, nematode worm counts and related morbidity markers, like pepsinogen for cattle and anaemia scores for sheep with haemonchosis, show moderate heritabilities (0.3-0.4), and this forms the basis for a breeding approach to control of gastrointestinal nematodes, as reviewed by e.g. [40] and [41]. In large wool producing countries (New Zealand and Australia) selective breeding for host resistance is now implemented on many commercial enterprises. Quantitative Trait Loci (QTLs) have been identified and a first DNA test for sheep is now commercially available (Catapult Genetics NZ) but breeding values are in most instances still based on faecal egg counts. Reduction rates in faecal egg counts are estimated to be approx. $2 \%$ annually [42] but the reduction in anthelmintic treatment frequency remains to been demonstrated. Selective breeding for resistance has been associated with disadvantages, e.g. low productivity when unexposed, or increased tendency to scouring associated with larval exposure, due to higher immunological responsiveness [43]. Combining low faecal egg counts with other traits, e.g. productivity, in a selection index is therefore presently considered most suitable [41].

In pigs, Danish studies based on examination of 200 offspring of known matings revealed heritabilities of faecal egg counts of A. suum of 0.3-0.4 and of T. suis of 0.4-0.7 [44]. For T. suis the heritabilities depended on time in relation to start of infection: during the early expulsion phase heritabilities were highest, probably indicating close genetic control of the onset of immunity. For Ascaris a number of other parameters like actual worm burden, total egg output and antibodylevels were also heritable whereas this was not the case for the size and fecundity of the worms (Peter Nejsum, unpublished data, 2009). It is obvious that breeding for increased host resistance is also an option within the pig industry and may be highly relevant in free-range systems.

\section{Conclusions}

Other options, apart from those mentioned above, remain, including biological control with nematode-trapping fungi against free-living larvae, copperoxide needles against abomasal nematodes, vaccination against gastrointestinal nematodes of sheep, etc. For different reasons these options are not expected to be available in the Nordic or Baltic context in the foreseeable future. In contrast, many forms of grazing management do work in ruminants and should always form the backbone of any control program. Nutritional supplementation to grazing ruminants is also immediately available but the costs and benefits need to be considered - if herbage amount and quality is sufficient very little extra is gained by additional supplementation. Selective breeding is an obvious option in small ruminants and perhaps in pigs and beef/dual purpose cattle. More basic research is needed on bioactive forages with regard to mode of action and possible active compounds in order to select 
the most appropriate forage species/cultivars. None of these approaches should be considered 'stand alone' control measures due to their moderate efficacy and integration with anthelmintics will continue to be a necessity.

Today it is widely recognized that with the limited arsenal of anthelmintics and the constant spread of anthelmintic resistance, we cannot keep livestock free of nematodes during their entire production life by drug application alone. We need to provide support for the susceptible young stock, e.g. optimal nutrition and limited parasite challenge, during the phase of acquisition of immunity until they can cope with infections. Thus, our mission as veterinarians and parasitologists has changed accordingly and a new approach to achieve sufficient levels of immunity with acceptable levels of production loss and uncompromised animal welfare by prudent (read minimal) use of anthelmintics has emerged. This represents a shift in paradigm, because previously the issue of most concern was achieving the highest production possible. Now we must consider how to transfer this new message 'across the fence' to farmers and extension staff. The future challenges are indeed numerous.

\section{Acknowledgements}

The authors are grateful for valuable comments from Dr. A. L. Willingham on an earlier version of this paper.

Published: 13 October 2010

\section{References}

1. Roepstorff A: Ascaris suum in pigs: population biology and epidemiology. Doctorate Thesis, The Royal Veterinary and Agricultural University, Copenhagen 2003, 227.

2. Waller PJ: Sustainable nematode parasite control strategies for ruiminant livestock by grazing management and biological control. Animal Feed Science and Technology 2006, 126:277-289.

3. Waller PJ, Thamsborg SM: Nematode control in 'green' ruminant production systems. Trends in Parasitology 2004, 20(10):493-497.

4. Barger I: Grazing Management for the Control of Nematode Parasites. Sustainable Parasite Control in Small Ruminants ACIARLF Le Jambre, MR Knox 1996, 146-150.

5. Thamsborg SM, Roepstorff A: Parasite problems in organic livestock production systems and options for control. Journal of Parasitology 2003, 89:S277-S284

6. Svensson C, Hessle A, Höglund J: Parasite control methods in organic and conventional dairy herds in Sweden. Livestock Production Science 2000, 66:57-69.

7. Weinreich $L L$, Thamsborg SM, Jensen AM, Vaarst M, Rasmussen J: Parasite control in Danish organic dairy herds and farmers' attitudes to agricultural production. Enhancing Animal Health Security and Food Safety in Organic Livestock Production. Proceedings of the 3rd SAFO Workshop. 16-18 September 2004, Falenty, Poland Sustaining Animal Health and Food Safety in Organic Farming, University of Reading, ReadingHovi, M., Zastawny, J. and Padel, S. 2005, 165.

8. Eysker M, van der Aar WM, Boersema JH, Githiori JB, Koyman FNJ: The effect of repeated moves to clean pasture on the build up of gastrointestinal nematode infections in calves. Veterinary Parasitology 1998, 76:81-94

9. Kristensen T, Thamsborg SM, Andersen HR, Søegaard K, Nielsen AL: Effects of grazing system on production and parasitism of dairy breed heifers and steers grazing wet marginal grasslands. Animal Science 2006, 82:201-211.

10. Larsson A, Dimander SO, Rydzik A, Uggla A, Waller PJ, Höglund J: A 3-year field evaluation of pasture rotation and supplementary-feeding to control parasite infection in first-season grazing cattle - Effects on animal performance. Veterinary Parasitology 2006, 142:197-206.

11. Barger I: Influence of sex and reproductive status on susceptibility of ruminants to nematode parasitism. International Journal for Parasitology 1993, 23:463-469.

12. Thamsborg SM, Jørgensen RJ, Nansen P: Internal parasitism of steers grazing extensively at different stocking rates. Acta vet. scand 1998, 39:311-323.

13. Thamsborg SM, Jørgensen RJ, Ranvig H, Bartlett P, Waller PJ, Nansen P: The performance of grazing sheep in relation to stocking rate and exposure to nematode infections. Livestock Production Science 1998, 53:265-277.

14. Thomsen LE, Mejer H, Wendt S, Roepstorff A, Hindsbo O: The influence of stocking rate on transmission of helminth parasites in pigs on permanent pasture during two consecutive summers. Veterinary Parasitology 2001, 99:129-146.

15. Svensson C: Survival of oocysts of Eimeria alabamensis on pastures under different climatic conditions in Sweden. Acta Vet. Scand 1995, 36:9-20.

16. Lindqvist A: Animal Health and Welfare in Organic Sheep and Goat Farming - Experiences and reflections from a Swedish outlook. In: Veterinary challenges in Organic Farming. Proc. 14th Nordic Committee for Veterinary Scientific Cooperation Symposium, Acta vet. Scand. 2001, 95:27-31.

17. Nielsen B, Thamsborg SM, Kristensen T: Feed supplements for young dairy breed calves after turn-out to pasture: Effect on weight gain and subclinical coccidiosis in organic production systems. Acta Agricultura Scandinavica, Section A, Animal Science 2003, 53:1-10.

18. Thamsborg SM, Githigia SM, Larsen ML, Nansen P, Henriksen SAa: Infektion med Nematodirus battus, en ny parasit hos får i Danmark (Nematodirus battus, a new parasitic infection in sheep in Denmark). Dansk Veterinærtidsskrift 1996, 79:231-232.

19. Pritchard GC, Forbes AB, Williams DJ, Salimi-Bejestani MR, Daniel RG: Emergence of fasciolosis in cattle in East Anglia. Vet.Rec 2005, 157:578-582.

20. Larsen MN, Roepstorff A: Seasonal variation in development and survival of Ascaris suum and Trichuris suis eggs on pastures. Parasitology 1999, 119:209-220

21. Roepstorff A, Murrell KD: Transmission dynamics of helminth parasites of pigs on continuous pasture: Oesophagostomum dentatum and Hyostrongylus rubidus. International Journal for Parasitology 1997, 27:553-562.

22. Mejer $\mathrm{H}$ : Transmission, infection dynamics and alternative control of helminths in organic swine. Ph. D. Thesis, The Royal Veterinary and Agricultural University, Copenhagen 2006.

23. Carstensen L, Vaarst M, Roepstorff A: Helminth infections in Danish organic swine herds. Veterinary Parasitology 2002, 106(3):253-264.

24. Roepstorff A, Jørgensen RJ, Nansen P, Henriksen SAa, Skovgaard J, Andreasen MPetersen: Parasitter hos økologiske svin (Parasites in certified organic production of swine). Project report from Danish Abattoirs 1992, 36.

25. Holmgren N, Nilsson O: Inverkan av produktionsplanering och skabbsanering på tarmnematoder hos bis-grisar (Influence of production planning and mange control on nematodes of pigs). Project report from Köttböndernas Forskningsprogram project No. G37-97, Svenska Djurhälsovården 1998.

26. Hoste H, Jackson F, Athanasiadou S, Thamsborg SM, Hoskin SO: The effects of tannin-rich plants on parasitic nematodes in ruminants. Trends in Parasitology 2006, 22(6):253-261.

27. Hoste H, Torres-Acosta JF, Alonso-Diaz MA, Brunet S, Sandoval-Castro C, Adote SH: Identification and validation of bioactive plants for the control of gastrointestinal nematodes in small ruminants. Proc. of 5th International Workshop: Novel Approaches to the Control of Helminth Parasites of Livestock. Tropical Biomedicine 2008, 25(1 Supplement):56-72.

28. Mueller-Harvey I: Unravelling the conundrum of tannins in animal nutrition and health. Journal of Science, Food and Agriculture 2006, 86:2010-2037.

29. Brunet $\mathrm{S}$, Jackson F, Hoste H: Effects of sainfoin (Onobrychis viciifolia) extract and monomers of condensed tannins on the association of 
abomasal larvae with fundic explants. International Journal for Parasitology 2008, 38:783-790.

30. Brunet S, Aufrere J, Babili F El, Fouraste I, Hoste H: The kinetics of exsheathment of infective nematode larvae is disturbed in the presence of a tannin-rich plant extract (sainfoin) both in vitro and in vivo. Parasitology 2007, 134:1253-1262.

31. Thamsborg SM, Mejer H, Bandier M, Larsen M: Influence of different forages on gastrointestinal nematode infections in grazing lambs. Proc. of 19th International Conference of WAAVP, New Orleans 2003, 189.

32. Bjørn $H$, Roepstorff A, Nansen P: A possible influence of diet composition on the establishment of nematodes in the pig. Veterinary Parasitology 1996, 63:167-171.

33. Petkevičius $\mathrm{S}$, BachKnudsen KE, Murrell KD, Wachmann $\mathrm{H}$ : The effect of inulin and sugar beet fibre on Oesophagostomum dentatum infection in pigs. Parasitology 2003, 127:61-68.

34. Petkevičius S, Bach Knudsen KE, Nansen P, Murrell KD: The effect of dietary carbohydrates with different digestibility on the populations of Oesophagostomum dentatum in the intestinal tract of pigs. Parasitology 2001, 123:315-324.

35. Petkevičius $S$, Murrell KD, Bach Knudsen KE, Jørgensen $H$, Roepstorff $A$, Laue A, Wachmann H: Effects of short-chain fatty acids and lactic acids on survival of Oesophagostomum dentatum in pigs. Veterinary Parasitology 2004, 122:293-301.

36. Mølbak L, Thomsen LE, Jensen TK, Knudsen KEB, Boye M: Increased amount of Bifidobacterium thermacidophilum and Megasphaera elsdenii in the colonic microbiota of pigs fed a swine dysentery preventive diet containing chicory roots and sweet lupine. Journal of Applied Microbiology 2007, 103(5):1853-1867.

37. Thomsen LE, Petkevičius S, Bach Knudsen KE, Roepstorff $A$ : The influence of dietary carbohydrates on experimental infection with Trichuris suis in pigs. Parasitology 2005, 131:857-865.

38. Petkevičius S, Thomsen LE, Bach Knudsen KE, Murrell KD, Roepstorff A, Boes J: The effect of inulin on new and on patent infections of Trichuris suis in growing pigs. Parasitology 2007, 134:121-127.

39. Thomsen LE, Knudsen KEB, Jensen TK, Christensen AS, Møller K, Roepstorff A: The effect of fermentable carbohydrates on experimental swine dysentery and whip worm infections in pigs. Veterinary Microbiology 2007, 119:152-163.

40. Sonstegard TS, Gasbarre LC: Genomic tools to improve parasite resistance. Veterinary Parasitology 2001, 101:387-403.

41. Hunt PW, McEwan JC, Miller JE: Future perspectives for the implementationm of genetic markers for parasite resistance in sheep. In: Proc. of 5th International Workshop: Novel Approaches to the Control of Helminth Parasites of Livestock. Tropical Biomedicine 2008, 25(1 Supplement):18-33.

42. Pomroy WE: Anthelmintic resistance in New Zealand: a perspective on recent findings and options for the future. New Zealand Veterinary Journal 2006, 54(6):265-270.

43. Karlsson LE, Pollott GE, Eady SJ, Bell A, Greeff JC: Relationship between faecal worm egg counts and scouring in Australian Merino sheep. Animal Production Australia 2004, 25:100-103.

44. Nejsum P, Roepstorff A, Jørgensen CB, Fredholm M, Göring HHH, Anderson TJC, Thamsborg SM: High heritability for Ascaris and Trichuris infection levels in pigs. Heredity 2009, 102:357-364.

doi:10.1186/1751-0147-52-S1-S27

Cite this article as: Thamsborg et al: Alternative approaches to control of parasites in livestock: Nordic and Baltic perspectives. Acta Veterinaria Scandinavica 2010 52(Suppl 1):S27.

\section{Submit your next manuscript to BioMed Central and take full advantage of:}

- Convenient online submission

- Thorough peer review

- No space constraints or color figure charges

- Immediate publication on acceptance

- Inclusion in PubMed, CAS, Scopus and Google Scholar

- Research which is freely available for redistribution

Submit your manuscript at www.biomedcentral.com/submit
Biomed Central 